【F: Table 2】

\title{
Applicability of Dry Flours Produced from a Table Potato Variety (Solanum tuberosum L. cv. May Queen) in Bread Making
}

\author{
Daiki Murayama ${ }^{1}$, Tomone Kimura ${ }^{1}$, Kazumasa Tsuboi ${ }^{1}$, Daiju YAmadA $^{1}$, Dennis Marvin Santiago ${ }^{2,3}$, \\ Hiroshi KOAZE ${ }^{1}$ and Hiroaki YamaUCHI ${ }^{1 *}$
}

${ }^{I}$ Department of Food Science, Obihiro University of Agriculture and Veterinary Medicine, West 2-11, Inada, Obihiro, Hokkaido, Japan

${ }^{2}$ The United Graduate School of Agricultural Science, Iwate University, 3-18-8 Ueda, Morioka, Iwate, Japan

${ }^{3}$ Food Science Cluster, College of Agriculture, University of the Philippines Los Baños, College, Laguna, Philippines 4031

Table 2. Dough properties and bread making qualities of dough and breads made with untreated, B and BR potato flours.

\begin{tabular}{|c|c|c|c|c|c|c|c|c|}
\hline \multirow{2}{*}{ Formulation } & \multirow{2}{*}{$\begin{array}{c}\text { Water absorption } \\
\text { of dough }(\%)\end{array}$} & \multirow{2}{*}{\multicolumn{2}{|c|}{$\begin{array}{l}\text { GRD } \\
(\mathrm{mL})\end{array}$}} & \multicolumn{3}{|c|}{ GP (mL) } & \multirow{2}{*}{$\begin{array}{c}\mathrm{SLV} \\
(\mathrm{mL} / \mathrm{g})\end{array}$} & \multirow{2}{*}{$\begin{array}{l}\text { Moisture content } \\
\text { of bread (\%) }\end{array}$} \\
\hline & & & & $1 \mathrm{~h}$ & $2 \mathrm{~h}$ & $3 \mathrm{~h}$ & & \\
\hline Control & 67.5 & $110.0 \pm 5.0$ & $\bar{b}$ & $28.3 \pm 0.4 \mathrm{a}$ & $64.3 \pm 2.0 \mathrm{a}$ & $97.7 \pm 3.3 \mathrm{c}$ & $4.70 \pm 0.14 b$ & $44.3 \pm 0.3 \mathrm{~b}$ \\
\hline $\mathrm{C}+$ Untreated & 65.0 & $95.0 \pm 0.0$ & d & $26.3 \pm 0.2 \mathrm{c}$ & $62.8 \pm 0.5 \mathrm{~b}$ & $108.2 \pm 0.8 \mathrm{~b}$ & $4.00 \pm 0.07 \mathrm{~cd}$ & $43.6 \pm 0.1 \mathrm{c}$ \\
\hline$C+10 B$ & 72.0 & $96.7 \pm 2.9$ & $\mathrm{~cd}$ & $28.0 \pm 0.2 \mathrm{ab}$ & $67.5 \pm 0.4 \mathrm{a}$ & $112.0 \pm 0.8 \mathrm{a}$ & $3.74 \pm 0.23 \mathrm{~d}$ & $45.7 \pm 0.3 \mathrm{a}$ \\
\hline$C+30 B$ & 72.5 & $101.7 \pm 2.9$ & $\mathrm{~cd}$ & $26.5 \pm 0.1 \mathrm{c}$ & $60.0 \pm 0.3 \mathrm{c}$ & $99.4 \pm 0.8 \mathrm{c}$ & $3.76 \pm 0.06 \mathrm{~d}$ & $45.7 \pm 0.2 \mathrm{a}$ \\
\hline $\mathrm{C}+10 \mathrm{BR}$ & 70.5 & $103.3 \pm 2.9$ & $\mathrm{bc}$ & $25.8 \pm 0.3 \mathrm{~d}$ & $61.1 \pm 1.0 \mathrm{c}$ & $102.2 \pm 2.5 \mathrm{c}$ & $4.11 \pm 0.05 \mathrm{~cd}$ & $44.8 \pm 0.0 \mathrm{~b}$ \\
\hline $\mathrm{C}+30 \mathrm{BR}$ & 72.0 & $96.7 \pm 2.9$ & $\mathrm{~cd}$ & $24.5 \pm 0.1 \mathrm{e}$ & $58.8 \pm 0.6 \mathrm{c}$ & $99.1 \pm 0.9 \mathrm{~cd}$ & $3.95 \pm 0.05 \mathrm{~cd}$ & $45.5 \pm 0.3 \mathrm{a}$ \\
\hline$\overline{\mathrm{Y}}$ & 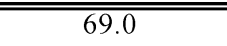 & $130.0 \pm 0.0$ & $\overline{\mathrm{a}}$ & $27.6 \pm 0.2 \mathrm{~b}$ & $63.5 \pm 0.5 \mathrm{~b}$ & $96.7 \pm 0.7 \mathrm{~d}$ & 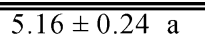 & $\bar{~} 44.8 \pm 0.2 \mathrm{~b}$ \\
\hline $\mathrm{Y}+10 \mathrm{BR}$ & 72.0 & $110.0 \pm 0.0$ & $\mathrm{~b}$ & $26.1 \pm 0.2 \mathrm{~cd}$ & $63.7 \pm 0.6 \mathrm{~b}$ & $106.3 \pm 0.8 \mathrm{~b}$ & $4.20 \pm 0.13 \mathrm{c}$ & $45.6 \pm 0.2 \mathrm{a}$ \\
\hline
\end{tabular}

Mean values in the same column with different letters are significantly different $(p<0.05)$.

Abbreviations: GRD, Gas retention of dough; GP, Total gassing power; SLV, Specific loaf volume

【T: Table 2】

Table 2. Properties of doughs and breads made from 8 different formulations of test flours.

\begin{tabular}{|c|c|c|c|c|c|c|c|c|}
\hline \multirow{2}{*}{ Formulation } & \multirow{2}{*}{$\begin{array}{c}\text { Water absorption } \\
\text { of dough }(\%)\end{array}$} & \multirow{2}{*}{\multicolumn{2}{|c|}{$\begin{array}{l}\text { GRD } \\
(\mathrm{ml})\end{array}$}} & \multicolumn{3}{|c|}{$\overline{\mathrm{GP}}(\mathrm{ml})$} & \multirow{2}{*}{$\begin{array}{c}\text { SLV } \\
(\mathrm{ml} / \mathrm{g})\end{array}$} & \multirow{2}{*}{$\begin{array}{c}\text { Moisture content } \\
\text { of bread }(\%)\end{array}$} \\
\hline & & & & $1 \mathrm{~h}$ & & $2 \mathrm{~h}$ & & \\
\hline Control & 67.5 & $110.0 \pm 5.0$ & $\mathrm{~b}$ & $28.3 \pm 0.4$ & $\mathrm{a}$ & $62.6 \pm 0.4$ bc & $4.70 \pm 0.14 \mathrm{~b}$ & $44.3 \pm 0.3 \mathrm{~b}$ \\
\hline $\mathrm{S}+\mathrm{D}$ & 65.0 & $95.0 \pm 0.0$ & d & $26.3 \pm 0.2$ & $\mathrm{c}$ & $62.8 \pm 0.5 \mathrm{bc}$ & $4.00 \pm 0.07 \mathrm{~cd}$ & $43.6 \pm 0.1 \mathrm{c}$ \\
\hline$S+10 B$ & 72.0 & $96.7 \pm 2.9$ & $\mathrm{~cd}$ & $28.0 \pm 0.2$ & $a b$ & $67.5 \pm 0.4 \mathrm{a}$ & $3.74 \pm 0.23 \mathrm{~d}$ & $45.7 \pm 0.3 \mathrm{a}$ \\
\hline $\mathrm{S}+30 \mathrm{~B}$ & 72.5 & $101.7 \pm 2.9$ & cd & $26.5 \pm 0.1$ & $\mathrm{c}$ & $60.0 \pm 0.3 \mathrm{~d}$ & $3.76 \pm 0.06 \mathrm{~d}$ & $45.7 \pm 0.2 \mathrm{a}$ \\
\hline $\mathrm{S}+10 \mathrm{BR}$ & 70.5 & $103.3 \pm 2.9$ & $\mathrm{bc}$ & $25.8 \pm 0.3$ & $\mathrm{~d}$ & $62.0 \pm 0.2 \mathrm{c}$ & $4.11 \pm 0.05 \mathrm{~cd}$ & $44.8 \pm 0.0 \mathrm{~b}$ \\
\hline $\mathrm{S}+30 \mathrm{BR}$ & 72.0 & $96.7 \pm 2.9$ & $\mathrm{~cd}$ & $24.5 \pm 0.1$ & $\mathrm{e}$ & $58.8 \pm 0.6 \mathrm{~d}$ & $3.95 \pm 0.05 \mathrm{~cd}$ & $45.5 \pm 0.3 \mathrm{a}$ \\
\hline$\overline{\mathrm{ESS}}$ & 69.0 & $130.0 \pm 0.0$ & $\overline{\mathrm{a}}$ & $27.6 \pm 0.2$ & $\overline{\mathrm{b}}$ & $63.5 \pm 0.5 \mathrm{~b}$ & $5.16 \pm 0.24$ a & 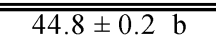 \\
\hline $\mathrm{ES}+10 \mathrm{BR}$ & 72.0 & $110.0 \pm 0.0$ & $\mathrm{~b}$ & $26.1 \pm 0.2$ & $\mathrm{~cd}$ & $63.7 \pm 0.6 \mathrm{~b}$ & $4.31 \pm 0.13 \mathrm{c}$ & $45.6 \pm 0.2 \mathrm{a}$ \\
\hline
\end{tabular}

Mean values in the same column with different letters are significantly different $(p<0.05)$.

Abbreviations: GRD, Gas retention of dough; GP, Total gassing power; SLV, Specific loaf volume 


\title{
Original paper
}

\section{Applicability of Dry Flours Produced from a Table Potato Variety (Solanum tuberosum L. cv. May Queen) in Bread Making}

\author{
Daiki Murayama ${ }^{1}$, Tomone Kimura ${ }^{1}$, Kazumasa Tsuboi ${ }^{1}$, Daiju YAmadA $^{1}$, Dennis Marvin Santiago ${ }^{2,3}$, \\ Hiroshi KoAZE ${ }^{1}$ and Hiroaki YAMAUChI ${ }^{1 *}$ \\ ${ }^{I}$ Department of Food Science, Obihiro University of Agriculture and Veterinary Medicine, West 2-11, Inada, Obihiro, \\ Hokkaido, 080-0834 Japan \\ ${ }^{2}$ The United Graduate School of Agricultural Science, Iwate University, 3-18-8 Ueda, Morioka, Iwate, 020-8550 Japan \\ ${ }^{3}$ Food Science Cluster, College of Agriculture, University of the Philippines Los Baños, College, Laguna, Philippines 4031
}

Received December 9, 2014 ; Accepted January 25, 2015

Five different potato flours were prepared from the table potato variety, May Queen, by drying potato slices without boiling or refrigeration (D), with boiling for 10 or $30 \mathrm{~min}(10 \mathrm{~B}, 30 \mathrm{~B})$ and with boiling for 10 or $30 \mathrm{~min}$, followed by refrigeration (10BR, 30BR), and their applicability to bread making was evaluated. When $10 \%$ potato flour was added to strong wheat flour (S), B and BR increased the water absorption of dough and lowered the gas retention of dough (GRD) and specific loaf volume (SLV). However, the highest GRD and SLV were observed in a combination of $S$ with 10BR among the tested flour blends. Furthermore, GRD and SLV were improved by replacing $S$ with extra-strong wheat flour (ES). The bread made from ES and 10BR maintained significantly higher softness of crumb compared to control during 3 days of storage at $20^{\circ} \mathrm{C}(p<0.05)$.

Keywords: potato flour, table potato, bread making quality, boiling, refrigeration

\section{Introduction}

Potato (Solanum tuberosum L.) is one of the major global crops, and has the highest quantity of production among all root and tuber crops in the world and Japan $\left(\mathrm{FAO}^{\mathrm{i})}\right)$. In Japan, the major potato varieties produced are classified into three-groups: table, processing, and starch extraction potatoes (Ministry of Agriculture, Forestry and Fisheries of Japan ${ }^{\text {ii) }}$ ). For table potatoes, external injury such as scuffing and bruising of the tuber negatively affects their market acceptability; and even though these potatoes are still safe to eat (Burton, 1989), they are typically diverted for starch extraction in Japan.

Aina et al., (2009) reported that the production of dry flour from sweet potato could help to reduce food losses, add value and increase earnings for farmers. Thus, the production of potato flour would be a better alternative for utilization of externally injured table potatoes than starch extraction. Potato flour is generally produced by blanching or cooking, drying, grinding and sieving of potato tubers (Kim and Kim, 2014). It has been recognized that physicochemical properties of potato flours are influenced by treatments such as heating (Yadav et al., 2006) and pectinase treatment (Kim and Kim, 2014). In addition, the application of potato flours to food products such as extruded puff (Faller and Heymann, 1996), cookies (Singh et al., 2003), and breads (Ijah et al., 2014) has been widely studied. In regards to bread making, however, it has been reported that non-wheat flours, such as cassava, corn, potato, rice, rye, soy and sweet potato flour, used to replace wheat flour wholly or partially lead to lower bread making qualities such as specific loaf volume (SLV), gas retention of dough (GRD) and acceptability compared to wheat flour breads (He and Hoseney, 1991; Eddy et al., 2007; Sabanis and Tzia, 2009; Ijah 
et al., 2014; Trejo-González et al., 2014). Ijah et al. (2014) further reported that partial replacement of wheat flour with $10 \%$ dehydrated uncooked potato flour resulted in a significant decrease in acceptability compared to wheat flour bread $(p<0.05)$. On the other hand, the addition of extra-strong wheat flour was reported to improve SLV and GRD of bread and dough made from mediumstrong wheat flour that is typically not suitable for bread making (Yamauchi et al., 1999; Yamauchi et al., 2003), and thus, extrastrong wheat flour can potentially improve bread quality because of its high gluten content (Hung et al., 2005).

Therefore, the objectives of the present study were to evaluate the applicability of 5 different potato flours produced from the table potato variety, May Queen, in bread making and assess the effect of introducing extra-strong wheat flour on bread making quality.

\section{Materials and Methods}

Raw materials A commercial table potato variety (Solanum tuberosum L. cv. May Queen) was purchased from a local market and used for preparation of potato flours.

Preparation of dry potato flour (D) Potato tubers were peeled, sliced to $1 \mathrm{~cm}$ thickness and dried in a hot air oven (WFO-700, TOKYO RIKAKIKI Co., Ltd., Tokyo, Japan) at $50^{\circ} \mathrm{C}$ for $48 \mathrm{~h}$. Dried slices were milled by a blender (New Power Mill PM-2005, OSAKA CHEMICAL Co., Ltd., Osaka, Japan) and sifted through a $300 \mu \mathrm{m}$ aperture sieve. The sample was stored at $4^{\circ} \mathrm{C}$ until use.

Preparation of boiled potato flours (B) Potato tubers were peeled, boiled in tap water for 10 or $30 \mathrm{~min}$ and then sliced, dried, milled and sieved in the same manner as above. Potato flours with boiling for 10 or $30 \mathrm{~min}$ were coded as $10 \mathrm{~B}$ and $30 \mathrm{~B}$, respectively and stored at $4^{\circ} \mathrm{C}$ until use.

Preparation of boiled and refrigerated potato flours (BR) Potato tubers were peeled, boiled in tap water for 10 or $30 \mathrm{~min}$ and then refrigerated in a polyethylene bag at $5^{\circ} \mathrm{C}$ for 5 days. The boiled and refrigerated potato tubers were sliced, dried, milled and sieved in the same manner as above. Potato flours with boiling for 10 or $30 \mathrm{~min}$ followed by refrigeration (10BR and $30 \mathrm{BR})$ were stored at $4^{\circ} \mathrm{C}$ until use.

Wheat flours Commercial strong wheat flour (S), Camellia, and extra-strong wheat flour (ES), Tsukinomahou, made from Triticum aestivum L. cv. Yumechikara, were purchased from Nisshin Flour Milling Co., Ltd. (Tokyo, Japan) and Yamamoto Tadanobu Shoten KK. (Hokkaido, Japan), respectively. Protein and ash contents of S and ES were 12.2 and $13.9 \%$, and 0.39 and $0.53 \%$, respectively (w/w, $13.5 \%$ moisture base).

Analytical determination of physicochemical properties of potato flours Moisture content was determined by the method of the Association of Official Analytical Chemists (AOAC) (2000). Damaged starch content was determined by a Megazyme assay kit based on the method of Gibson et al. (1991) (Megazyme International Co., Ltd., Bray, Ireland). Particle size distribution was determined by a compact laser diffraction particle size analyzer (Helos \& Rodos, Sympatec GmbH, Clausthal-Zellerfeld, Germany). $L^{*}, a^{*}$ and $b^{*}$ as color properties were determined by a color difference meter (CR410, Konica Minolta, Inc., Tokyo, Japan).

Bread making The no-time method was used for bread making with the standard white bread formulation as the control, consisting of $200 \mathrm{~g}$ of S, $10 \mathrm{~g}$ of sugar, $10 \mathrm{~g}$ of shortening (Snowlight, Kaneka Corp., Osaka, Japan), $4 \mathrm{~g}$ of salt, $4 \mathrm{~g}$ of wet yeast (Regular yeast, Nippon Beet Sugar Mfg. Co., Ltd., Tokyo, Japan), $20 \mathrm{mg}$ of L-ascorbic acid and a suitable quantity of water. The dough was mixed to just beyond peak development, divided into $100 \mathrm{~g}$ pieces, rounded and allowed to rest for $20 \mathrm{~min}$ at $30^{\circ} \mathrm{C}$ and $75 \%$ humidity as bench time. The pieces were panned, proofed at $38^{\circ} \mathrm{C}$ and $85 \%$ humidity for $70 \mathrm{~min}$ and then baked at $200^{\circ} \mathrm{C}$ for 18 min. (Yamauchi et al., 1992; Yamauchi et al., 2001). The optimal water absorption of dough was determined by a Farinograph at $500 \mathrm{BU}$, according to the AACC method (1991). For preparing breads from $\mathrm{S}$ with potato flours, $10 \% \mathrm{~S}$ was partially replaced with potato flours. In addition, $\mathrm{S}$ was replaced by ES.

Analytical determination of dough properties Twenty gram of dough after proofing was used for measuring the gas retention of dough (GRD) by the method of Yamauchi et al. (2000). Maximum volume of dough in a cylinder under low pressure was used for evaluation of GRD. The total gassing power (GP) with $20 \mathrm{~g}$ of dough after bench time was measured at $30^{\circ} \mathrm{C}$ for $2 \mathrm{~h}$ with a Fermograph II (ATTO Co., Ltd., Tokyo, Japan).

Analytical determination of bread properties Specific loaf volume (SLV) of bread was measured by the rapeseed displacement method after cooling the bread at room temperature for $1 \mathrm{~h}$ after baking. Bread crumbs $(2 \mathrm{~cm} \times 3 \mathrm{~cm} \times 3 \mathrm{~cm})$ were dried for $3 \mathrm{~h}$ at $135^{\circ} \mathrm{C}$ for determining moisture content (AOAC, 2000). Images of breads were obtained using a digital camera (EX-H15, Casio Computer Co., Ltd., Tokyo, Japan), while images of individual slices from breads were photocopied using a scanner (GT-9800F, Seiko Epson Corp., Nagano, Japan). $L^{*}, a^{*}$ and $b^{*}$ as color properties were determined using a color difference meter (CR410, Konica Minolta, Inc., Tokyo, Japan) at the center of the sliced loaf as crumb color. Hardness of bread crumb during storage was evaluated using a creep meter (RE2-33005C, Yamaden Co., Ltd., Tokyo, Japan). Loaves cooled for $1 \mathrm{~h}$ at room temperature after baking were packed into polyethylene bags and stored at $20^{\circ} \mathrm{C}$ and $70 \%$ humidity. After storage for 24,48 and $72 \mathrm{~h}$, the loaves were sliced at $2 \mathrm{~cm}$ thickness and a $3 \mathrm{~cm} \times 3 \mathrm{~cm}$ square was cut from the center of each slice. The maximum stress as hardness was measured by compressing the crumbs from $2 \mathrm{~cm}$ thickness to $1 \mathrm{~cm}$ thickness with $1 \mathrm{~mm} / \mathrm{s}$ of compression rate using a square plunger $(6 \mathrm{~cm} \times 6 \mathrm{~cm}$ contact surface, silicon $)$.

Statistical analysis Statistical analyses were conducted using SPSS for Windows (ver. 17.0). One-way analysis of variance and Tukey's multiple-range test were carried out for comparison of 
Table 1. Physicochemical properties of D, B and BR potato flours.

\begin{tabular}{|c|c|c|c|c|c|c|c|c|}
\hline Treatment & $\begin{array}{c}\text { Moisture } \\
(\%)\end{array}$ & & $\begin{array}{c}\text { Damaged starch } \\
(\%, d w b)\end{array}$ & $\begin{array}{l}\text { Mean particle } \\
\text { size }(\mu \mathrm{m})\end{array}$ & $L^{*}$ & $a^{*}$ & & $b^{*}$ \\
\hline $\bar{D}$ & $9.71 \pm 0.08$ & $\mathrm{c}$ & $9.15 \pm 0.43 \mathrm{e}$ & $41.28 \pm 0.97$ & $83.37 \pm 0.11 \mathrm{~d}$ & $0.91 \pm 0.03$ & $\mathrm{a}$ & $13.92 \pm 0.32 \mathrm{~b}$ \\
\hline $10 \mathrm{~B}$ & $10.36 \pm 0.04$ & $\mathrm{a}$ & $48.80 \pm 1.37 b$ & $82.24 \pm 3.73$ & $89.71 \pm 0.40$ & $-1.65 \pm 0.24$ & $\mathrm{e}$ & $13.91 \pm 0.72 b$ \\
\hline $30 \mathrm{~B}$ & $9.38 \pm 0.05$ & d & $51.45 \pm 0.76 \mathrm{a}$ & $69.03 \pm 2.67$ & $89.15 \pm 0.17 b$ & $-0.83 \pm 0.14$ & $\mathrm{c}$ & $15.39 \pm 0.46 \mathrm{a}$ \\
\hline 10BR & $10.42 \pm 0.02$ & $\mathrm{a}$ & $35.20 \pm 0.53 \mathrm{~d}$ & $76.33 \pm 1.53$ & $88.99 \pm 0.03 b$ & $-1.20 \pm 0.23$ & $\mathrm{~d}$ & $14.11 \pm 0.78 b$ \\
\hline 30BR & $9.98 \pm 0.08$ & $\mathrm{~b}$ & $39.97 \pm 0.55 \mathrm{c}$ & $59.55 \pm 0.82$ & $88.48 \pm 0.09 c$ & $-0.22 \pm 0.10$ & b & $15.11 \pm 0.17 \mathrm{a}$ \\
\hline
\end{tabular}

Mean values in the same column with different letters are significantly different $(p<0.05)$.

physicochemical properties of potato flours among 5 treatments, and dough and bread properties among 8 different formulations at a $5 \%$ significance level. Correlation analysis was performed to evaluate the relationship between dough and bread properties.

\section{Results and Discussion}

Physicochemical properties of potato flours Table 1 indicates moisture content, damaged starch content, mean particle size, $L^{*}$, $a^{*}$ and $b^{*}$ of potato flours. Moisture and damaged starch contents of potato flours ranged from 9.38 to $10.42 \%$ and 9.15 to $51.45 \%$ dry weight basis (dwb), respectively. The highest content of damaged starch was observed in $30 \mathrm{~B}$ among all potato flours $(p<0.05)$. 10BR showed the lowest damaged starch content among B and BR $(p<0.05)$. Yadav et al. (2006) reported that heat treatments such as blanching and steaming during potato flour production cause significant increases of damaged starch content. Furthermore, it was reported that steam treatment of cassava flour resulted in the degradation of crystalline regions of starch, and subsequent drying and milling processes may have caused greater mechanical damage to the pre-gelatinized starch (Murayama et al., 2014). Thus, the major causes of the significant increase in damaged starch content of B and BR compared to that of D may also be due to the drying and milling processes of gelatinized starch. 10BR and 30BR had significantly lower contents of damaged starch than the corresponding non-refrigerated potato flours, and it was observed that the refrigeration process led to significant decreases in damaged starch content $(p<0.05)$. Storage of gelatinized potato starch at $4^{\circ} \mathrm{C}$ has been reported to cause starch retrogradation observed by differential scanning calorimetry (Gunaratne and Hoover, 2002). Therefore, the decrease in damaged starch content of BR may be attributed to the partial recrystallization and retrogradation of gelatinized starch by refrigeration.

Mean particle size of potato flours varied between $41.28 \mu \mathrm{m}$ and $82.24 \mu \mathrm{m}$. 10B, 10BR, 30B and 30BR had significantly higher mean particle size than that of D. Andersson et al. (1994) reported that starch granules in potato tuber cells absorb cellular water and swell to form a gel during heating. Hence, boiling may have increased the mean particle size by the swelling and adhering of gelatinized starch granules.

Color properties of $L^{*}, a^{*}$ and $b^{*}$ ranged from 83.37 to 89.71 ,
-1.65 to 0.91 and 13.91 to 15.39 for potato flours, respectively. D showed significantly lower $L^{*}$ and higher $a^{*}$ among all potato flours $(p<0.05)$, and these results may be due to the browning of potato slices during drying, caused by enzymes such as polyphenol oxidases (Martinez and Whitaker, 1995). Therefore, it seems that boiling can improve the color of potato flours. Jangchud et al. (2003) also reported that color properties of orange and purple sweet potato flour are improved by blanching slices in water at $90-95^{\circ} \mathrm{C}$ for $1 \mathrm{~min} .30 \mathrm{~B}$ and $30 \mathrm{BR}$ had significantly higher $b^{*}$ among all potato flours $(p<0.05)$. Higher $b^{*}$ indicates higher yellow color, and longer boiling increased the yellowness of potato flours.

Dough and bread properties Properties of dough and breads made from 8 different formulations are shown in Table 2 and Fig. 1. The addition of $10 \mathrm{~B}, 30 \mathrm{~B}, 10 \mathrm{BR}$ and $30 \mathrm{BR}$ caused an increase in the water absorption of dough compared to the control and the dough made from $\mathrm{S}$ with D. These results agreed with Purhagen et al. (2008), who reported that partial replacement of wheat flour with heat-treated barley flour leads to increases in the water absorption of dough compared to the control and the dough made with a wheat and normal barley flour blend. Moreover, it was reported that damaged starch absorbs more water than unmodified starch at temperatures lower than the gelatinization temperature (Lelievre, 1974). Thus, the addition of B and BR, which had a higher content of damaged starch, may have increased the water absorption of dough. In addition, the higher water absorption of the doughs made from $\mathrm{S}$ with $10 \mathrm{~B}$ and $30 \mathrm{~B}$ compared to their refrigerated counterparts may also be due to the higher content of damaged starch.

GRD ranged from 95.0 to $130.0 \mathrm{~mL}$ among all doughs, and the dough made from $\mathrm{S}$ with $\mathrm{D}$ had the lowest GRD $(p<0.05)$. The doughs made from $\mathrm{S}$ with potato flours showed lower GRD than the control. Gan et al. (1995) indicated that the quantity and quality of gluten proteins determine the rheological properties of optimally mixed dough and thus contribute to gas retention properties of fermenting dough. Therefore, a reduction in the relative concentration of gluten proteins by the addition of potato flours may have contributed to the decrease in GRD for the doughs with added potato flours. In addition, Yamauchi et al. (2004) and Santiago et al. (2014) reported that the gluten network of dough becomes weaker and rougher and GRD decreases when rice or 
Table 2. Properties of doughs and breads made from 8 different formulations of test flours.

\begin{tabular}{|c|c|c|c|c|c|c|c|c|}
\hline \multirow{2}{*}{ Formulation } & \multirow{2}{*}{$\begin{array}{c}\text { Water absorption } \\
\text { of dough }(\%)\end{array}$} & \multirow{2}{*}{\multicolumn{2}{|c|}{$\begin{array}{l}\text { GRD } \\
(\mathrm{ml})\end{array}$}} & \multicolumn{3}{|c|}{ GP (ml) } & \multirow{2}{*}{$\begin{array}{c}\text { SLV } \\
(\mathrm{ml} / \mathrm{g})\end{array}$} & \multirow{2}{*}{$\begin{array}{l}\text { Moist ure content } \\
\text { of bread (\%) }\end{array}$} \\
\hline & & & & $1 \mathrm{~h}$ & & $2 \mathrm{~h}$ & & \\
\hline Control & 67.5 & $110.0 \pm 5.0$ & $\mathrm{~b}$ & $28.3 \pm 0.4 \mathrm{a}$ & $\bar{a}$ & $62.6 \pm 0.4 \mathrm{bc}$ & $4.70 \pm 0.14 \mathrm{~b}$ & $44.3 \pm 0.3 \mathrm{~b}$ \\
\hline $\mathrm{S}+\mathrm{D}$ & 65.0 & $95.0 \pm 0.0$ & d & $26.3 \pm 0.2 \mathrm{c}$ & $\mathrm{c}$ & $62.8 \pm 0.5 \mathrm{bc}$ & $4.00 \pm 0.07 \mathrm{~cd}$ & $43.6 \pm 0.1 \mathrm{c}$ \\
\hline $\mathrm{S}+10 \mathrm{~B}$ & 72.0 & $96.7 \pm 2.9$ & $\mathrm{~cd}$ & $28.0 \pm 0.2 \mathrm{a}$ & $a b$ & $67.5 \pm 0.4 \mathrm{a}$ & $3.74 \pm 0.23 \mathrm{~d}$ & $45.7 \pm 0.3 \mathrm{a}$ \\
\hline $\mathrm{S}+30 \mathrm{~B}$ & 72.5 & $101.7 \pm 2.9$ & $\mathrm{~cd}$ & $26.5 \pm 0.1 \mathrm{c}$ & $\mathrm{c}$ & $60.0 \pm 0.3 \mathrm{~d}$ & $3.76 \pm 0.06 \mathrm{~d}$ & $45.7 \pm 0.2 \mathrm{a}$ \\
\hline$S+10 B R$ & 70.5 & $103.3 \pm 2.9$ & $\mathrm{bc}$ & $25.8 \pm 0.3 \mathrm{~d}$ & d & $62.0 \pm 0.2 \mathrm{c}$ & $4.11 \pm 0.05 \mathrm{~cd}$ & $44.8 \pm 0.0 \mathrm{~b}$ \\
\hline $\mathrm{S}+30 \mathrm{BR}$ & 72.0 & $96.7 \pm 2.9$ & $\mathrm{~cd}$ & $24.5 \pm 0.1 \mathrm{e}$ & e & $58.8 \pm 0.6 \mathrm{~d}$ & $3.95 \pm 0.05 \mathrm{~cd}$ & $45.5 \pm 0.3 \mathrm{a}$ \\
\hline 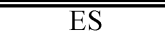 & 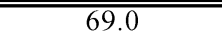 & 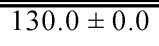 & 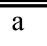 & $27.6 \pm 0.2 \mathrm{~b}$ & $\overline{\mathrm{b}}$ & $63.5 \pm 0.5 \mathrm{~b}$ & $=5.16 \pm 0.24 \mathrm{a}$ & 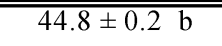 \\
\hline $\mathrm{ES}+10 \mathrm{BR}$ & 72.0 & $110.0 \pm 0.0$ & $\mathrm{~b}$ & $26.1 \pm 0.2 \mathrm{c}$ & $\mathrm{cd}$ & $63.7 \pm 0.6 \mathrm{~b}$ & $4.31 \pm 0.13 \mathrm{c}$ & $45.6 \pm 0.2 \mathrm{a}$ \\
\hline
\end{tabular}

Mean values in the same column with different letters are significantly different $(p<0.05)$.

Abbreviations: GRD, Gas retention of dough; GP, Total gassing power; SLV, Specific loaf volume

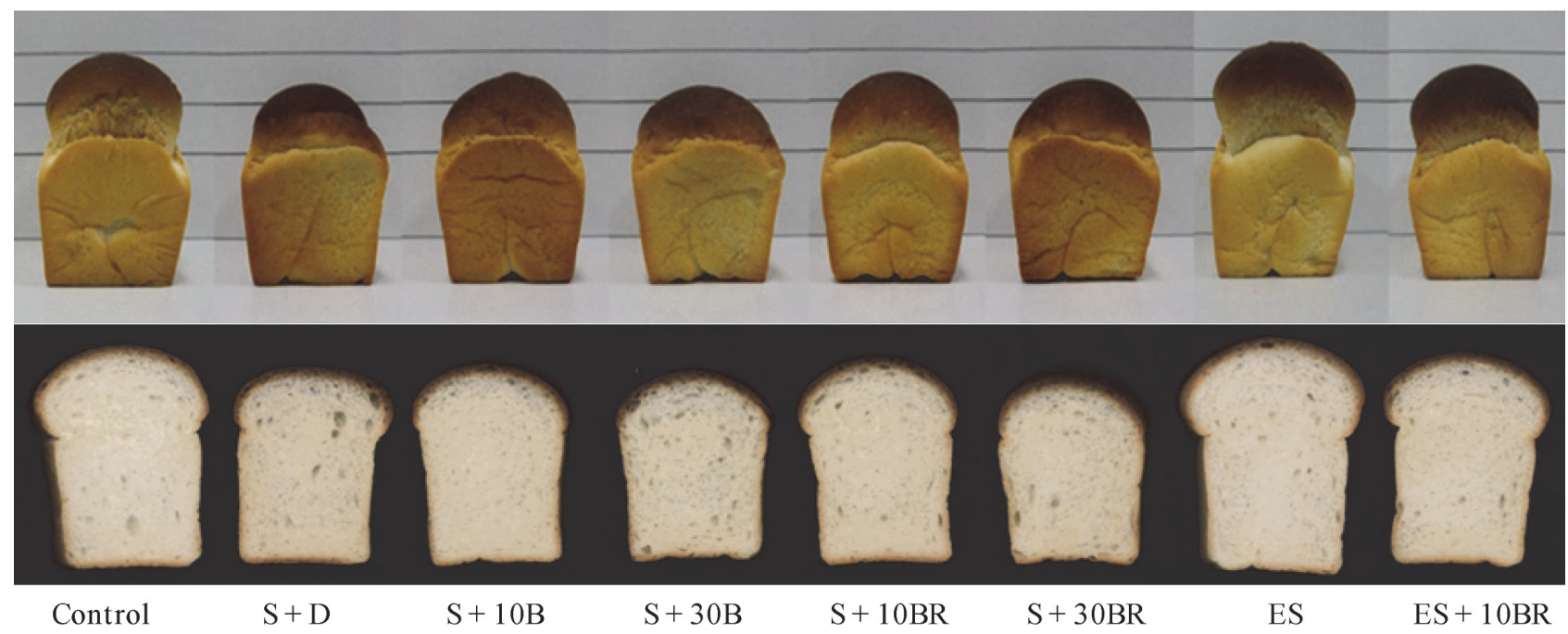

Fig. 1. Photographs and scanned images of breads and bread crumbs made from 8 different formulations of test flours.

sweet potato flours are added to wheat flour. Wheat flour replacement of $\mathrm{S}$ with ES caused a significant increase of GRD, and this result agreed with the report of Yamauchi et al. (2001) on breads made with medium-soft, strong and extra-strong wheat flours. Furthermore, the dough made from ES with 10BR maintained a GRD equivalent to the control.

GP of doughs made with 8 different formulations were $24.5-28.3 \mathrm{~mL}$ and $58.8-67.5 \mathrm{~mL}$ at $1 \mathrm{~h}$ and $2 \mathrm{~h}$ fermentation, respectively. The addition of $30 \mathrm{~B}$ and $30 \mathrm{BR}$ to dough resulted in significantly lower GP compared to the corresponding doughs with added $10 \mathrm{~B}$ and $30 \mathrm{~B}$ throughout the fermentation period $(p<0.05)$. McCance et al. (1936) reported that the boiling of peeled potato tuber caused decreased contents of soluble constituents such as carbohydrates and minerals. Thus, this decrease in GP for 30B and 30BR added doughs may be due to leaching of fermentable substrates such as soluble sugars by prolonged boiling. The doughs made from $\mathrm{S}$ with $10 \mathrm{BR}$ and $30 \mathrm{BR}$ showed lower GP than those of the corresponding non-refrigerated potato flours, $10 \mathrm{~B}$ and $30 \mathrm{~B}$, throughout the fermentation period. Refrigeration significantly lowered the content of damaged starch in potato flours in the present study, and Lelievre (1974) indicated that damaged starch is more susceptible to enzymatic degradation. In addition, it is well known that wheat flour contains amylolytic enzymes such as $\alpha$ - and $\beta$-amylase (Kent, 1966); such amylolytic enzymes are responsible for potato starch degradation and the production of lower molecular weights sugars, and further increase the fermentable substrates available for yeast (Burton, 1989; Greene and Bovell-Benjamin, 2004). Therefore, refrigeration following the boiling process restricted gas production in the doughs.

$\mathrm{SLV}$ ranged between $3.74 \mathrm{~mL} / \mathrm{g}$ and $5.16 \mathrm{~mL} / \mathrm{g}$, and significantly higher SLV was observed in the bread made with ES, followed by the control. A comparison of SLV among breads made from $\mathrm{S}$ with potato flours, the bread made from S with 10BR showed the highest SLV. B or BR addition led to lower SLV than the breads made with S or ES. Similar observations were reported by Greene and Bovell-Benjamin (2004), Hathorn et al. (2008) and Santiago et al. (2014) on decreases in SLV caused by sweet potato flour addition to wheat dough. According to He and Hoseney (1991), SLV is mainly influenced by two factors: GP and GRD. In the present study, there was no significant correlation between GP and SLV ( $r=0.101-0.399)$, while a highly significant positive correlation between GRD and SLV was observed $(r=0.921$, $p<0.01$ ), which agreed with the report by He and Hoseney (1991). Hence, GRD may be the primary factor affecting SLV in the 
Table 3. Color properties of bread crumbs made from tested formulations.

\begin{tabular}{cccccc}
\hline Formulation & $L^{*}$ & $a^{*}$ & $b^{*}$ \\
\hline Control & $78.76 \pm 1.68 \mathrm{ab}$ & $-2.16 \pm 0.13$ & $\mathrm{bc}$ & $9.08 \pm 0.74 \mathrm{e}$ \\
$\mathrm{S}+\mathrm{D}$ & $74.40 \pm 1.61 \mathrm{~d}$ & $-1.77 \pm 0.04$ & $\mathrm{a}$ & $12.05 \pm 0.51 \mathrm{~b}$ \\
$\mathrm{~S}+10 \mathrm{~B}$ & $77.76 \pm 1.45 \mathrm{abc}$ & $-2.45 \pm 0.10$ & $\mathrm{e}$ & $10.84 \pm 0.53 \mathrm{~cd}$ \\
$\mathrm{~S}+30 \mathrm{~B}$ & $77.19 \pm 2.19 \mathrm{bc}$ & $-2.27 \pm 0.07$ & $\mathrm{~cd}$ & $10.45 \pm 0.71 \mathrm{~cd}$ \\
$\mathrm{~S}+10 \mathrm{BR}$ & $79.68 \pm 0.95 \mathrm{a}$ & $-2.44 \pm 0.06$ & $\mathrm{e}$ & $11.27 \pm 0.38 \mathrm{bc}$ \\
$\mathrm{S}+30 \mathrm{BR}$ & $78.76 \pm 1.25 \mathrm{ab}$ & $-2.13 \pm 0.04$ & $\mathrm{~b}$ & $10.67 \pm 0.37$ & $\mathrm{~cd}$ \\
\hline \hline ES & $77.16 \pm 0.93 \mathrm{bc}$ & $-1.84 \pm 0.03$ & $\mathrm{a}$ & $10.04 \pm 0.26 \mathrm{~d}$ \\
ES + 10BR & $75.28 \pm 2.09 \mathrm{~cd}$ & $-2.31 \pm 0.09$ & $\mathrm{~d}$ & $13.12 \pm 0.70$ & $\mathrm{a}$ \\
\hline
\end{tabular}

Mean values in the same column with different letters are

significantly different $(p<0.05)$.

present study. SLV of breads was significantly increased by wheat flour replacement of S with ES, and this result agreed with the report by Yamauchi et al. (2001) on breads made with mediumsoft, strong or extra-strong wheat flour. The bread made from ES with 10BR had the highest SLV among breads with added potato flours. This improvement of SLV may be due to the formation of a greater gluten network by the extra-strong wheat flour.

The highest moisture contents were observed in the breads made from $\mathrm{S}$ with $10 \mathrm{~B}$ and $30 \mathrm{~B}$ among all breads. On the other hand, the bread made from $\mathrm{S}$ with $\mathrm{D}$ showed significantly lower moisture content $(p<0.05)$, which may have resulted from the lowest water absorption among all doughs.

Table 3 indicates the color properties of crumbs from the breads of 8 different formulations. $L^{*}, a^{*}$ and $b^{*}$ ranged from 74.40 to $79.68,-2.45$ to -1.77 and 9.08 to 13.12 , respectively. Significantly higher $b^{*}$ was observed in the bread made from ES with 10BR $(p<0.05)$, and all breads with added potato flours had higher $b^{*}$ than that of the control. The bread made from $\mathrm{S}$ with $\mathrm{D}$ showed the lowest $L^{*}$ among all breads $(p<0.05)$. The primary reason for this decrease in $L^{*}$ may be the addition of $\mathrm{D}$, which had a significantly lower $L^{*}$ among all potato flours $(p<0.05)$. Thus, it was recognized that the boiling of potatoes improved not only $L^{*}$ of potato flours but also that of bread crumbs with added potato flours.

Figure 2 illustrates the changes in crumb hardness for breads made from 8 different formulations during storage. Hardness of all bread crumbs increased in a similar linear manner throughout the storage periods. In a comparison of hardness at all storage periods, there were no significant differences between the control and the breads made from $\mathrm{S}$ with $10 \mathrm{~B}, 10 \mathrm{BR}, 30 \mathrm{~B}$ and $30 \mathrm{BR}$, while significantly higher hardness was observed in the bread made from $\mathrm{S}$ with D $(p<0.05)$. According to Maleki et al. (1980), higher moisture content and larger loaf volume produce a softer bread, and thus the highest hardness of the bread made from S with D may result from the lowest moisture content and smaller SLV. Wheat flour replacement of S with ES led to significantly lower hardness, i.e., higher softness of the bread crumbs than the control throughout the storage periods $(p<0.05)$. This increase in softness of the bread made from ES may be attributed to the significantly higher SLV $(p<0.05)$. The bread made from ES with $10 \mathrm{BR}$

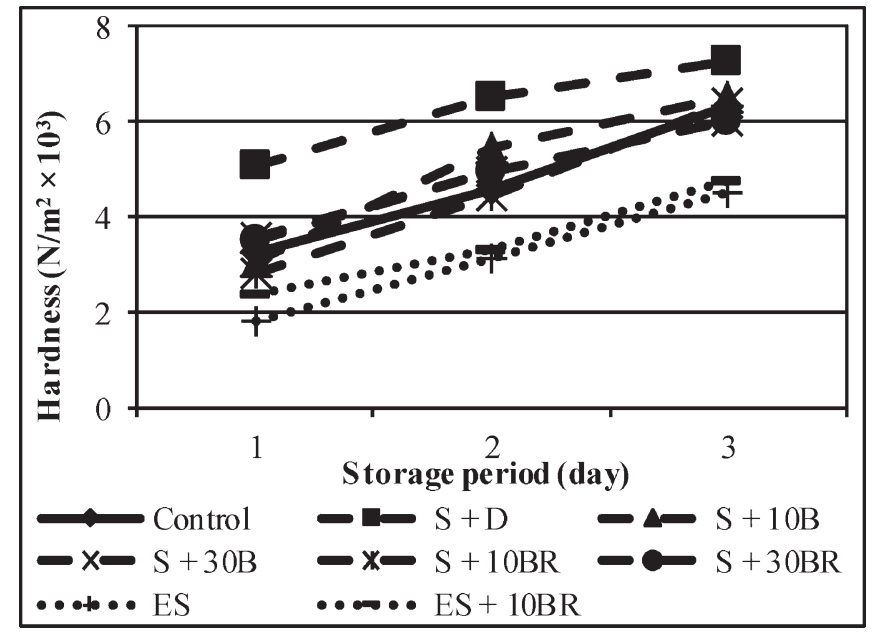

Fig. 2. The changes of crumb hardness during storage of breads made from tested formulations.

maintained significantly higher softness than the control, and did not significantly differ from the bread made from ES during 3 days of storage $(p<0.05)$. Higher SLV by ES addition and relatively higher moisture content by addition of 10BR may contribute to the higher softness of the bread made from ES with 10BR.

\section{Conclusion}

D, B and BR exhibited different physicochemical properties such as moisture content, damaged starch content, mean particle size and color properties. It was observed that refrigeration during potato flour production caused a significant decrease in damaged starch content $(p<0.05)$. Boiling led to improved color properties such as $L^{*}$ and $a^{*}$ for $\mathrm{B}$ and $\mathrm{BR}$, which may have resulted from the inhibition of enzymatic browning. In a comparison of the water absorption of doughs, the doughs made from S with B and BR had higher values than the control and the dough made from $\mathrm{S}$ with $\mathrm{D}$, possibly due to the higher content of damaged starch. The addition of potato flours to wheat flour resulted in lower GRD than the control. In a comparison of SLV among breads made from $\mathrm{S}$ with potato flours, the bread made from $S$ with 10BR showed the highest SLV. The bread made from ES with 10BR showed higher SLV than those of other breads made from $S$ with potato flours. Since B and BR had significantly higher $L^{*}(p<0.05)$, the breads made from $\mathrm{S}$ with $\mathrm{B}$ and $\mathrm{BR}$ had significantly higher $L^{*}$ than that of the bread made from $S$ with D. Moreover, the bread made from ES with 10BR maintained a significantly higher bread crumb softness than that of the control during 3-day storage $(p<0.05)$. It was revealed that boiling and refrigeration processes during potato flour production and selection of extra-strong wheat flour improved bread making quality. Therefore, BR produced from the table potato variety, May Queen, appears to have high applicability to bread making.

\section{References}

AACC (1991). "Approved methods of the AACC", 8th ed., AACC, St. 
Paul, MN.

AOAC (2000). "Official methods of analysis", 17th ed., AOAC International, Gaithersburg, MD.

Andersson, A., Gekas, V., Lind, I., Oliveira, F., Öste, R., and Aguilfra, J. M. (1994). Effect of preheating on potato texture. Crit. Rev. Food Sci. Nutr., 34, 229-251.

Aina, A. J., Falade, K. O., Akingbala, J. O., and Titus, P. (2009). Physicochemical properties of twenty-one Caribbean sweet potato cultivars. Int. J. Food Sci. Technol., 44, 1696-1704.

Burton, W. G., (1989). “The potato”, 3rd ed., Longman, London.

Eddy, N. O., Udofia, P. G., and Eyo, D. (2007). Sensory evaluation of wheat/cassava composite bread and effect of label information on acceptance and preference. Afr. J. Biotechnol., 6, 2415-2418.

Faller, J. Y. and Heymann, H. (1996). Sensory and physical properties of extruded potato puffs. J. Sens. Stud., 11, 227-245.

Gan, Z., Ellis, P. R., and Schofield, J. D. (1995). Gas cell stabilisation and gas retention in wheat bread dough. J. Cereal Sci., 21, 215-230.

Gibson, T.S., Al Qalla, H., and McCleary, B. V. (1991). An improved enzymatic method for the measurement of starch damage in wheat flour. J. Cereal Sci., 15, 15-27.

Greene, J. L. and Bovell - Benjamin, A. C. (2004). Macroscopic and sensory evaluation of bread supplemented with sweet - potato flour. $J$. Food Sci., 69, 167-173.

Gunaratne, A. and Hoover, R. (2002). Effect of heat-moisture treatment on the structure and physicochemical properties of tuber and root starches. Carbohydr. Polym., 49, 425-437.

Hathorn, C. S., Biswas, M. A., Gichuhi, P. N., and Bovell-Benjamin, A. C. (2008). Comparison of chemical, physical, micro-structural, and microbial properties of breads supplemented with sweetpotato flour and high-gluten dough enhancers. LWT-Food Sci. Technol., 41, 803-815.

Hung, P. V., Maeda, T., Yamauchi, H., and Morita, N. (2005). Dough and breadmaking properties of various strong wheat grains cultivated in Japan. J. Appl. Glycosci., 52, 15-21

He, H. and Hoseney, R. C. (1991). Gas retention of different cereal flours. Cereal Chem., 68, 334-336.

Ijah, U. J. J., Auta, H. S., Aduloju, M. O., and Aransiola, S. A. (2014). Microbiological, nutritional, and sensory quality of bread produced from wheat and potato flour blends. Int. J. Food Sci., 2014, 1-6.

Jangchud, K., Phimolsiripol, Y., and Haruthaithanasan, V. (2003). Physicochemical properties of sweet potato flour and starch as affected by blanching and processing. Starch - Stärke, 55, 258-264.

Kent, N. L. (1966). "Technology of cereals, with special reference to wheat", 1st ed., Pergamon press, Oxford.

Kim, E. J. and Kim, H. S. (2014). Influence of pectinase treatment on the physicochemical properties of potato flours. Food Chem.. 167, 425-432

Lelievre, J. (1974). Starch damage. Starch-Stärke, 26, 85-88.

Maleki, M., Hoseney, R. C., and Mattern, P. J. (1980). Effects of loaf volume, moisture content, and protein quality on the softness and staling rate of bread. Cereal Chem., 57, 138-140.

Martinez, M. V. and Whitaker, J. R. (1995). The biochemistry and control of enzymatic browning. Trends Food Sci. Technol., 6, 195-200.
McCance, R. A., Widdowson, E. M., and Shagkleton, L. (1936). "The nutritive value of fruits, vegetables and nuts”, Her Majesty's Stationery Office, London.

Murayama, D., Kasano, M., Santiago, D. M., Yamauchi, H., and Koaze, H. (2014). Effect of pre-gelatinization on the physicochemical properties of dry flours produced from 5 cassava varieties of the Philippines. Food Sci. Technol. Res., 20, 1131-1140.

Purhagen, J. K., Sjöö, M. E., and Eliasson, A. C. (2008). Staling effects when adding low amounts of normal and heat-treated barley flour to a wheat bread. Cereal Chem., 85, 109-114.

Sabanis, D. and Tzia, C. (2009). Effect of rice, corn and soy flour addition on characteristics of bread produced from different wheat cultivars. Food Bioprocess Technol., 2, 68-79.

Santiago, D. M, Matsushita, K., Noda, T., Tsuboi, K., Yamada, D., Murayama, D., Koaze, H., and Yamauchi, H. (2014). Effect of purple sweet potato powder substitution and enzymatic treatments on bread making quality. Food Sci. Technol. Res., In press.

Singh, J., Singh, N., Sharma, T. R., and Saxena, S. K. (2003). Physicochemical, rheological and cookie making properties of corn and potato flours. Food Chem., 83, 387-393.

Trejo-González, A. S., Loyo-González, A. G., and Munguía-Mazariegos, M. R. (2014). Evaluation of bread made from composite wheat-sweet potato flours. Int. Food Res. J., 21, 1683-1688.

Yadav, A. R., Guha, M., Tharanathan, R. N., and Ramteke, R. S. (2006). Influence of drying conditions on functional properties of potato flour. Eur. Food Res. Technol., 223, 553-560.

Yamauchi, H., Fujimura, M., Ohya, K., Hirakawa, T., and Kobayashi, T. (1992). Role of shortening and monoglyceride on staling of white bread made by straight dough method. Nihon Shokuhin Kogyo Gakkaishi, 39, 383-390 (in Japanese).

Yamauchi, H., Ichinose, Y., Takata, K., Iriki, N., and Kuwabara, T. (2000). Simple estimation of bread-making quality of wheat flour by modified expansion test under reduced pressure. Nihon Shokuhin Kagaku Kogaku Kaishi, 47, 46-49 (in Japanese).

Yamauchi, H., Nishio, Z., Takata, K., Oda, Y., Yamaki, K., Ishida, N., and Miura, H. (2001). The bread-making quality of a domestic flour blended with an extra strong flour and staling of the bread made from the blended flour. Food Sci. Technol. Res., 7, 120-125.

Yamauchi, H., Noda, T., Matsuura Endo, C., Nishio, Z., Takata, K., Tabiki, T., and Iriki, N. (2003). Improving domestic flour for bread making by blending extra strong (ES) flour. Food Preserv. Sci., 29, 211-220.

Yamauchi, H., Noda, T., Matsuura-Endo, C., Takigawa, S., Saito, K., Oda, Y., and Hashimoto, N. (2004). Bread-making quality of wheat/rice flour blends. Food Sci. Technol. Res., 10, 247-253.

Yamauchi, H., Takata, K., and Yamaki, K. (1999). The new application technology of extra strong wheat flour to breads and noodles. Shokuhinkogyo, 43, 31-38.

\section{URL Cited}

i) http://www.fao.org/ (Aug. 21, 2014)

ii) http://www.maff.go.jp/ (Aug. 21, 2014) 